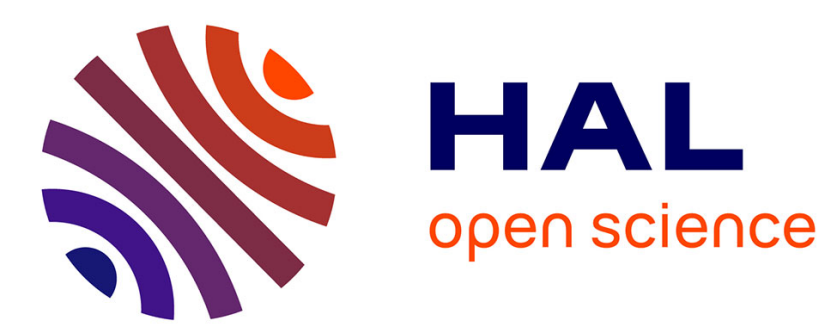

\title{
Income Taxation and the Diversity of Consumer Goods: A Political Economy Approach
}

\author{
Renaud Bourlès, Michael Dorsch, Paul Maarek
}

\section{To cite this version:}

Renaud Bourlès, Michael Dorsch, Paul Maarek. Income Taxation and the Diversity of Consumer Goods: A Political Economy Approach. Scandinavian Journal of Economics, 2019, 121 (3), pp.960993. 10.1111/sjoe.12307 . hal-02474671

\section{HAL Id: hal-02474671 \\ https://hal-amu.archives-ouvertes.fr/hal-02474671}

Submitted on 11 Feb 2020

HAL is a multi-disciplinary open access archive for the deposit and dissemination of scientific research documents, whether they are published or not. The documents may come from teaching and research institutions in France or abroad, or from public or private research centers.
L'archive ouverte pluridisciplinaire HAL, est destinée au dépôt et à la diffusion de documents scientifiques de niveau recherche, publiés ou non, émanant des établissements d'enseignement et de recherche français ou étrangers, des laboratoires publics ou privés. 


\title{
InCOME TAXATION AND THE Diversity OF Consumer Goods: A Political Economy APPROACH*
}

\author{
Renaud Bourlès ${ }^{1}$, Michael T. Dorsch ${ }^{2}$, and Paul Maarek ${ }^{3}$ \\ ${ }^{1}$ Centrale Marseille, Marseille, 13451, France, renaud.bourles@centrale-marseille.fr \\ ${ }^{2}$ Central European University, Budapest, 1051, Hungary, dorschm@ceu.edu \\ ${ }^{3}$ Université de Cergy-Pontoise, Cergy-Pontoise, 95011, France, paul.maarek@u-cergy.fr
}

\begin{abstract}
After-tax income inequality has risen since the mid-1990's, as increases in market income inequality have not been offset by greater fiscal redistribution. This paper argues that the substantial increase in consumer goods diversity has mitigated mounting political pressures for redistribution. Within a probabilistic voting framework, we demonstrate that if the share of diversified goods in the consumption bundle increases sufficiently with income, then an increase in goods diversity can reduce the political equilibrium tax rate. Focusing on OECD countries, we find empirical support for both the model's micro-political foundations and the implied relation between goods diversity and fiscal policy outcomes.
\end{abstract}

Keywords: Variety, Redistribution, Probabilistic voting, Non-homothetic preferences, Panel data

JEL codes: D72, D78, H24

Suggested running head: Income Taxation and the Diversity of Consumer Goods

\footnotetext{
*Bourlès: Aix-Marseille Univ., CNRS, EHESS, Centrale Marseille, AMSE; Dorsch: Central European University, School of Public Policy; Maarek: Université de Cergy-Pontoise, Department of Economics. The authors would like to thank two anonymous referees, the AMSE, the EPCS, Pierre Boyer, Yann Bramoullé, Cecilia Garcia-Penalosa, Erich Gundlach and George Tridimas.
} 


\section{Introduction}

In the last decades, many countries have experienced a strong increase in market income inequality that fiscal redistribution did not offset, leading to a significant increase in net income inequality (Piketty, 2014 and see Figure 1). This led the IMF to state in its last report (Gupta and Keen, 2014 and see Figure 1) that reductions in the generosity of welfare benefits and less progressive taxation have decreased the redistributive impact of fiscal policy. ${ }^{1}$ This paper seeks to add a new perspective to this now classic puzzle in political economy: why democracies do not redistribute more and what are the political economic limits to redistribution. More specifically, we investigate why democracies have not offset the strong increase in income inequality over the last decades.

We relate this limit to redistribution to the considerable increase in the variety of consumer goods available in developed economies (see Figure 1 and Broda and Weinstein, 2004, 2006; Hummels and Klenow, 2005; Arkolakis, Demidova, Klenow, and Rodriguez-Clare, 2008 for empirical evidence). ${ }^{2}$ This increase seems mostly due to the increases in $\operatorname{trade}^{3}$ and in $R \& D$ spending, including the effects of R\&D spillovers from abroad (Coe et al., 2009). ${ }^{4}$ The key idea of our paper is that this increase in goods diversity may have moderated the tendency for a society to compensate the increases in inequality by redistributing more. Figure 1 shows that average income tax rates on average incomes have gone down and that fiscal freedom (as measured by the Heritage Foundation) has increased. ${ }^{5}$ Central to our argument is the intuition that the welfare impacts of greater goods diversity may have been heterogeneous

\footnotetext{
1 Gupta and Keen (2014) show that between the mid-1980s and mid-1990s, fiscal policy offset about two-thirds of the 3.1 percentage point increase in market income inequality. Over the subsequent decade (mid-1990s to mid-2000s), fiscal policy only offset about one-fifth of the 2.2 percentage point increase in the market income inequality.

${ }^{2}$ Bils and Klenow (2001) estimate that growth in the number of varieties of goods has accelerated since 1980, and Broda and Weinstein (2006) estimate that the number of varieties (at the ten-digits level) available to consumers from trade flows has risen from 71,420 in 1971 to 259,215 in 2001. More importantly, the number of goods categories (within which there are several varieties of one good) has increased from 7,731 in 1972 to 16,390 in 2001 .

${ }^{3}$ For example, an increase in diversity is an essential feature of trade models with monopolistic competition (Krugman, 1979).

${ }^{4}$ The theoretical part of our paper considers this increase in goods diversity as exogenous.

${ }^{5}$ For details concerning these variables, we refer readers to the empirical section of the paper.
} 


\section{Empirical Evidence from OECD Countries}
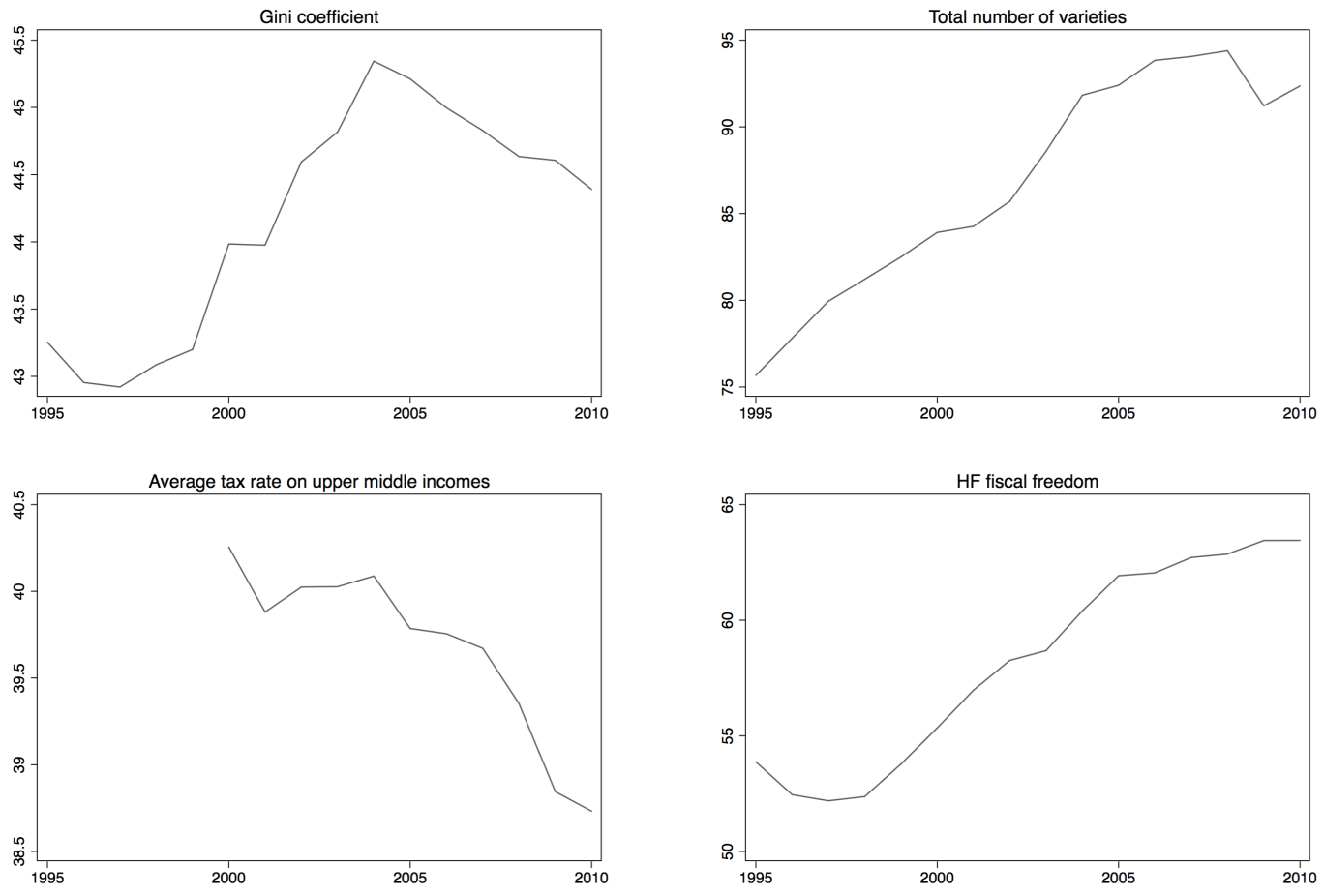

Figure 1: The evolution over the last decades of income inequality, the variety of goods, and fiscal outcomes. Note that the Gini coefficient is increasing in the degree of inequality and that the Heritage Foundation index is increasing the degree of fiscal freedom. All variables are expressed as the yearly average over the OECD.

across individuals, depending on the share of differentiated goods in individuals' consumption bundles. In this paper we analyze how such heterogeneous welfare effects of growth in the diversity of goods may have impacted individual preferences for fiscal redistribution, given that private consumption becomes more valuable as goods diversity increases. We then show how such a change in policy preferences may have affected the equilibrium income tax rate within a political economic model.

More specifically, we build a model of probabilistic voting in which voters spend their net (after taxes and transfers) income in private markets for two types of goods: one homogenous and one that is a composition of varieties. The "diversity of goods" then corresponds to the number of varieties in the composite good. The key mechanism of our model comes from a different allocation of income between those two types of goods for different income levels. 
The intuition for this mechanism goes back to Engel's Law (Engel, 1857), which states that the share of food in household spending decreases with income, and which we suppose extends to other basic goods (clothing, shelter, transport, energy, health and sanitation, etc). The share of "normal" goods and services (those that are not necessities) in the consumption bundle should increase with income as a result (see Bils and Klenow, 2001; Henry, 2014, 2015, for empirical evidence).

We assert that basic goods are produced mainly in competitive domestic markets that did not benefit from the massive productivity gains of the past decades, nor from the accompanying increases in trade volumes (for instance, international prices for many food commodities have increased over the last decades). In this case, the introduction of new goods and services and the subsequent increase in diversity should mainly affect the quantity of "normal" differentiated goods available for consumers, which are often produced in non-competitive markets with positive profits for producers. If the "Engel effect" described above applies, then the increase in the diversity of goods and services should benefit disproportionately the relatively rich consumers who allocate a higher share of income to those goods. ${ }^{6}$ We use a political economic model to examine the consequences for fiscal redistribution of such an asymmetric gain from increasing goods diversity.

In our baseline model, individuals form policy preferences for a progressive income tax (and the resulting lump-sum transfer that satisfies the government's budget constraint), which is the only policy dimension over which politicians compete. Following Lindbeck and Weibull (1987), we analyze political competition using a probabilistic voting model, which seems to more realistically capture the complexity of individual policy preferences and does not necessarily degenerate into a "median-voter" political equilibrium. ${ }^{7}$ The impact of an

\footnotetext{
${ }^{6}$ This diversity (or quantity) effect complements the price effect usually identified in the trade literature (Feenstra and Romalis, 2014), which concludes that trade benefits more the relatively poor consumers (Fajgelbaum and Khandelwal, 2016). This literature, however only considers the effect of trade on relative prices, whereas we focus here on a expansion in the number of varieties. Furthermore, in the latter paper, welfare gains are expressed as a percentage of equivalent expenditure, while our concern here is about absolute effects on utility. Our Engel effect assumption is compatible with their findings.

${ }^{7}$ The reason for using a probabilistic voting model is twofold. First, it takes into account the multidimensionality of the policy space. In the probabilistic voting framework, two individuals with the same
} 
increase in goods diversity on taxation depends on two competing effects. First, if all agents had the same consumption structure, an increase in the number of varieties would increase marginal utility by more for poorer agents, due to the concavity of the utility function in consumption levels. This effect therefore favors redistribution toward the poor when goods diversity increases. The second effect goes through the above-mentioned "Engel effect" of income on consumption structure. If, due to non-homothetic preferences, richer agents allocate a higher share of income to the diversified good, they benefit more from an increase in goods diversity. In this case, fiscal redistribution should decrease with goods diversity. We show that if preferences are sufficiently non-homothetic (i.e., if the share of the diversified good in the consumption bundle is sufficiently responsive to increases in income), then the second effect dominates. We derive the parametric conditions on preferences under which the second effect dominates and, as a result, an increase in the diversity of goods decreases the income tax rate in the political equilibrium. ${ }^{8}$

Our paper contributes to the literature on the determinants of income redistribution. According to the standard Romer-Roberts-Meltzer-Richard (RRMR) median voter model, inequality is one of the main determinants of the level of fiscal redistribution and the size of government (Romer, 1975; Roberts, 1977; Meltzer and Richard, 1981), which is also the case in the probabilistic voting model we employ. However, there is no clear evidence of this simple and intuitive mechanism in the empirical literature. Bénabou (1996), for example, cites ten studies out of which nine did not find evidence consistent with the RRMR model. More importantly, those models generally predict very high levels of redistribution, much higher income do not necessarily vote for the same candidate even if the two candidates have different electoral platforms concerning the tax rate. Second, voting behavior is then random and both candidates design the electoral platform in order to maximize the probability of winning. Therefore any change that modifies the marginal utility for one group of agents leads to a change in the optimal policy platform (the income tax rate in our framework).

${ }^{8}$ Our general model can be applied to other cases. The basic mechanism hinges on the fact that, due to non-homothetic preferences over a set of goods, any modification in the relative price (or price index) of two goods (or more) translates into a change in the relative price index of the consumption baskets of poor and rich individuals. Many factors may explain such a divergence in the evolution of the price of goods which enter in different proportions in the consumption basket of different individuals. Technological progress, for instance, has decreased the price of many high-end consumer goods that are consumed mainly by the rich. 
than the existing levels observed in many OECD countries. This puzzling evidence has been documented by numerous papers including Harms and Zink (2003), Gradstein and Milanovic (2004), Borck (2007) or more recently, Acemoglu et al. (2015). What happened the last two decades is a perfect illustration of this puzzle. As noted by Slemrod and Bakija (2008), Bonica et al. (2013) and Gupta and Keen (2014), tax and transfer systems did not compensate for the strong increase in market income inequality to the extent that would be predicted by the RRMR model and net inequality levels have increased as a result. ${ }^{9}$ According to Piketty (2014), fiscal reform is a major explanation of the increase in net income inequality observed the last decades.

As a result, an important area of research has focused on why the advanced democracies do not redistribute more, and relatedly why the strong increase in market income inequality has not been countered with greater redistribution. Epple and Romer (1991), for instance, propose an explanation based on fiscal competition between jurisdictions, which lowers the preferred tax rate of median income individuals since a high tax rate reduces the tax base when agents "vote with their feet" (see Wilson, 1999 for a survey). Increasing geographic mobility of (relatively rich) people could explain the decrease in the progressivity of tax and transfer systems all over the world. This seems to be particularly the case for top-earners (Kleven et al., 2013, 2014; Martinez, 2016). However, recent empirical papers have questioned the impact of such a mobility on effective tax rates by finding a very small (Isen, 2014) or even negative correlation (Chirinko and Wilson, 2017 or Parchet, 2014) between neighborjurisdiction tax rates. ${ }^{10}$ Moreover, recent research has questioned an underlying premise of the tax competition theory, that workers are indeed geographically mobile enough to shape the political agenda (Autor and Dorn, 2013). Still, in the empirical part of the paper, we

\footnotetext{
${ }^{9}$ The Congressional Budget Office also reports that the gap between market income and net income inequalities has remained very stable in the U.S. over the last three decades (Harris and Sammartino, 2011). Transfers did not decrease in absolute terms, but they have not offset at all the increase in market inequality over the same period, leading to an increase in after-tax inequality.

${ }^{10}$ This result seems to be robust across countries and jurisdiction level: Isen (2014) studies local referenda in the American state of Ohio, Chirinko and Wilson (2017) work on a panel of 48 contiguous U.S. states and Parchet (2014) uses tax reforms made in some Swiss provinces as a quasi-natural experiment.
} 
focus on income tax rates for the middle and upper-middle income groups, rather than the top income group, to abstract from the possible effect of fiscal competition on the equilibrium tax rate for top income groups.

Another typical argument is that poor voters sometimes prefer politicians with antiredistributive policy platforms due to party affinity or to the politicians' stances on noneconomic issues, which can limit equilibrium redistribution (see Dixit and Londregan, 1996 or Roemer, 1998, for example). Also, the influence of special interest lobby groups (as in Becker, 1983, Austin-Smith, 1987 and Grossman and Helpman, 2001) or the role of social status (see Corneo and Gruner, 2000) may prevent redistribution. Finally, the social mobility of voters may affect preferences for redistribution. Bénabou and Ok (2001) argue that the probability of becoming rich in the future can also moderate the redistributive ambitions of the current median voter. ${ }^{11}$

By putting forward the role played by the significant increase in the diversity of goods, we offer an alternative and complementary political economic explanation for the observed uncompensated increase in market income inequality in the advanced economies over the last few decades.

We then present some empirical evidence in line with our theoretical implications. Using trade data at the 6 digit level and the methodology developed by Broda and Weinstein (2006) we are able to compute the number of (traded) varieties (domestic and foreign) to which a consumer has access. We provide two types of evidence supporting our theory. We first focus on aggregate macro data over a panel of OECD countries and demonstrate that increases in our proxies for goods diversity are related to the drop in average tax rates during this period, as predicted by our model. We then mobilize international survey data from the World Values Survey (WVS) and the European Values Survey (EVS) in order to investigate the political support for pro-redistribution policies. We show that an increase in good diversity is associated with a decrease in the preference for redistribution (proxied by

\footnotetext{
${ }^{11}$ See also Dorsch (2010), which extends the analysis to consider public expenditure, more generally.
} 
the self-positioning on the political scale). Interestingly the effect is substantially stronger for relatively richer individuals, in line with our theory. This makes the policy platform shift to policies more at the right of the political scale, which we quite naturally associate with a decrease in redistribution.

The rest of the paper is organized as follows. Section 2 presents the general theoretical setup. Section 3 discusses the effect of an increase in goods variety on the equilibrium tax rate. Section 4 presents an extension to public goods. Section 5 is devoted to the empirical investigation and section 6 concludes.

\section{The general theoretical set up}

\section{Preferences and market equilibrium}

To analyze the effect of an increase of goods diversity we adopt the canonical monopolistic competition model of Dixit and Stiglitz (1977). ${ }^{12}$ Agents are endowed with income $I$ and can consume $n+1$ goods: a quantity $q_{0}$ of a static good (the numeraire) and quantities $q_{i}, i=1, \ldots, n$ of $n$ varieties of a differentiated good ( $n$ being large enough). We suppose that preferences depend on both $q_{0}$ and an index $Q$ composed of quantities of differentiated goods $q_{i}: Q=\left(\sum_{i=1}^{n} q_{i}^{\rho}\right)^{1 / \rho}$. We denote the index $Q$ quantity of the composite good, where $0 \leq \rho \leq 1$ represents the substitution or "love-of-variety" parameter. We describe these preferences by a utility function $U\left(q_{0}, Q\right)$, increasing and concave in both arguments (that is $U_{1}>0, U_{2}>0, U_{11} \leq 0$ and $U_{22} \leq 0$, where $f_{h}$ represents the derivative of $f$ with respect to its $h^{\text {th }}$ argument). We assume independence between consumption of the static and the composite goods, i.e. $U_{12}=0$; and note $R R A\left(q_{0}, Q\right) \equiv \frac{-Q U_{22}\left(q_{0}, Q\right)}{U_{2}\left(q_{0}, Q\right)}-$ respectively

\footnotetext{
${ }^{12}$ We focus here on horizontal differentiation. This renders consumer choice over varieties easier to model and to include in a more general model of non-homothetic preferences. An alternative specification would be to use discrete choices in a model including both horizontal and vertical differentiation as in Fajgelbaum et al. (2011). The effect of an increase in diversity, that is an increase in the set of goods among which the consumer can choose, would however be less easily tractable. Still, our result would remain in such a model provided that the marginal utility of income increases more for richer individuals, following an increase in diversity. This may be the case, for instance, if the increase in diversity comes from higher quality goods.
} 
$R P\left(q_{0}, Q\right) \equiv \frac{-Q^{*} U_{222}\left(q_{0}^{*}, Q^{*}\right)}{U_{22}\left(q_{0}^{*}, Q^{*}\right)}$ - the index of relative risk aversion - resp. relative prudence with respect to the differentiated good. In the working paper version of the paper (Bourlès et al., 2014) we also considered log-linear utility over the diversified good.

Agents optimally choose quantities to maximize their utility from consumption subject to budget constraint:

$$
\begin{aligned}
& \max _{q_{0},\left(q_{i}\right)_{i=1}^{n}} U\left(q_{0},\left(\sum_{i=1}^{n} q_{i}^{\rho}\right)^{\frac{1}{\rho}}\right) \\
& \text { s.t. } \quad q_{0}+\sum_{i=1}^{n} p_{i} q_{i} \leq I .
\end{aligned}
$$

As in the standard model, the prices $p_{i}$ are determined by monopolist competition, i.e., in markets for differentiated goods. Since $n$ is large, a change in $q_{i}$ has little effect on $\sum_{j=1}^{n} q_{j}^{\rho}$ and therefore on $U_{1}$ and $U_{2}$. The demand function can therefore be approximated by $q_{i}=k p_{i}^{-\frac{1}{1-\rho}}$, with $k>0$ and the demand elasticity for product $i$ is approximately $\epsilon_{i}=-\frac{\partial q_{i} / \partial p_{i}}{q_{i} / p_{i}}=\frac{1}{1-\rho}$. The producer of good $i$, chooses $p_{i}$ in order to maximize his profit: $\max _{p_{i}}\left(p_{i}-c\right) q_{i}-f$ where $c$ represents the constant marginal cost of production and $f$ the fixed cost. It follows that: $p_{i}\left(1-\frac{1}{\epsilon_{i}}\right)=c$ or $p_{i}=c / \rho$.

Therefore, using symmetry $\left(q_{i}=q \forall i\right)$, we can formulate the following remark regarding the equilibrium values of consumption and income effects.

Remark 1. The market equilibrium $\left(q_{0}^{*}, q^{*}\right)$ is defined by:

$$
\begin{aligned}
& q_{0}^{*}=I-P \cdot Q^{*} \\
& c U_{1}\left(I-P \cdot Q^{*}, Q^{*}\right)=n^{\frac{1}{\rho}-1} \rho U_{2}\left(I-P \cdot Q^{*}, Q^{*}\right),
\end{aligned}
$$

where $Q^{*} \equiv n^{\frac{1}{\rho}} q^{*}$ and $P \equiv \frac{n^{1-\frac{1}{\rho}} c}{\rho}$ represents the price index of the differentiated goods. Consequently:

1. The consumption of each good is increasing in income $\left(\frac{\partial q^{*}}{\partial I} \geq 0\right.$ and $\left.\frac{\partial q_{0}^{*}}{\partial I} \geq 0\right)$. 
2. Richer agents will allocate more of their extra income (if any) to consumption of the composite good $\left(\frac{\partial^{2} q^{*}}{\partial I^{2}}>0\right)$ if and only if :

$$
\frac{U_{111}\left(q_{0}^{*}, Q^{*}\right)}{\left[U_{11}\left(q_{0}^{*}, Q^{*}\right)\right]^{2}}<P \cdot \frac{U_{222}\left(q_{0}^{*}, Q^{*}\right)}{\left[U_{22}\left(q_{0}^{*}, Q^{*}\right)\right]^{2}}
$$

Proof. see Appendix.

Although the validity of condition (3) is difficult to assess empirically, its counterpart in terms of consumption: $\frac{\partial^{2} q^{*}}{\partial I^{2}}>0$ seems empirically relevant. As the static good corresponds here to necessary goods whereas the diversified good corresponds to all other goods and services (not needed to satisfy basic needs), it seems natural to consider that $\frac{\partial^{2} q^{*}}{\partial I^{2}}>0 .{ }^{13}$ This would simply correspond to the Engel effect: the share of goods satisfying basic needs in the consumption bundle should decrease with income. This seems to be in line with empirical evidence. For instance, Henry $(2014,2015)$ uses a consumer expenditure survey to study the expenditure structure of the consumption basket for different income quintiles in the U.S. ${ }^{14}$ For the lowest income quintile, the share of necessary goods goes from $63.5 \%$ in 1984 (first observation in the survey) to $54.5 \%$ in 2013. For the highest quintile, this share goes from $33.8 \%$ in 1984 to $27.7 \%$ in 2013. Bils and Klenow (2001) moreover document a quality Engel Curve for the U.S. which suggests that non-homotheticities are also observed within goods categories. Rich individuals consume higher quality goods at higher prices.

\footnotetext{
${ }^{13}$ Other papers consider such a hierarchical demand for goods and non-homothetic preferences. For instance, Matsuyama (2002) considers food as a necessary good that is homogeneous. In his model an increase in the number of varieties will only increase consumption possibilities for the rich given the fact that the poor still have many varieties to consume they not consumed yet. We adopt a more nuanced perspective in this paper, in which also the poor consumers can benefit from an increase in the number of varieties.

${ }^{14}$ Goods are classified according to whether the expenditure share in income of each category respectively increases, does not change or decreases with income quintiles. Some examples of goods that are classified as basic necessities, those whose expenditure share is decreasing with income level, are the following: food at home, rented dwellings, utilities, fuels, public services, healthcare, education, personal care, tobacco and smoking products, necessity gas and motor oil, and housekeeping supplies, for example.
} 


\section{Political equilibrium}

To model the political environment, we begin by borrowing the standard model of redistributive politics, which we slightly modify in order to allow for progressive taxation and probabilistic voting. Without loss of generality, we assume two income classes of agents indexed by $j=\{L ; H\}$ with respective incomes $I^{L}$ and $I^{H}\left(>I^{L}\right)$ and respective proportions $\alpha^{L}$ and $\alpha^{H} .{ }^{15}$ We consider redistribution via a transfer $T$ to low-income (type $L$ ) consumers financed by a linear income tax $\tau$ on high-income (type $H$ ) consumers. ${ }^{16}$ After-tax income thus equals $\widehat{I}^{H}(\tau)=(1-\tau) I^{H}$ for high-income consumers and $\widehat{I}^{L}(\tau)=I^{L}+T$ for low-income consumers; the government's budget constraint giving $T=\tau\left(\alpha^{H} / \alpha^{L}\right) I^{H}$. We then naturally have $\partial \widehat{I}^{L} / \partial \tau>0$ and $\partial \widehat{I}^{H} / \partial \tau<0$. To ease interpretation, it is useful to rewrite income as a function of average income $\widetilde{I} \equiv \sum_{j} \alpha^{j} I^{j}: I^{L}=\theta \widetilde{I} / \alpha^{L}$ and $I^{H}=(1-\theta) \widetilde{I} /\left(1-\alpha^{L}\right)$, where $\theta \equiv \alpha^{L} I^{L} / \widetilde{I}$ is a measure of inequality.

Voters have to choose between two candidates, $A$ and $B$, who offer tax rates $\tau_{A}$ and $\tau_{B}$ as policy platforms, respectively. We suppose that the political equilibrium level of taxation is determined according to the probabilistic voting model of Lindbeck and Weibull (1987). In the probabilistic voting model, voter $i$ in group $j$ prefers candidate $A$ (to candidate $B$ ) if

$$
U^{j}\left(\tau_{A}\right)>U^{j}\left(\tau_{B}\right)+\sigma^{i}+\delta
$$

where $U^{j}(\tau)$ represents the utility achieved by agents of group $j$ when the tax is $\tau$, i.e., $U^{j}(\tau) \equiv U\left(q_{0}^{*}\left(\widehat{I}^{j}(\tau)\right), Q^{*}\left(\widehat{I}^{j}(\tau)\right)\right)$; idiosyncratic individual preferences for candidate $A$ are represented by the random parameter $\sigma^{i}$, which is assumed to be uniformly distributed over the support $\left[-\frac{1}{2 \phi}, \frac{1}{2 \phi}\right]$; and $\delta$ is a random parameter that represents the population's

\footnotetext{
${ }^{15}$ We could have considered non linear income taxation with heterogeneous ability and endogenous efforts of agents within our political competition framework (see Bierbrauer and Boyer 2013, for instance). However, in our view, making income of agents endogenous would not change the nature of our result. The main mechanism comes here for income differences between groups and redistribution at equilibrium. This can be obtained in an optimal taxation framework under reasonable assumptions.

${ }^{16}$ In the working paper version of the article (Bourlès et al., 2014), we consider a lump sum transfer $T$ financed by a linear income tax $\tau$ on all incomes. Results remain the same.
} 
preference for candidate $A$, which is assumed to be uniformly distributed over the support $\left[-\frac{1}{2 \xi} ; \frac{1}{2 \xi}\right]$. Distributions of $\sigma^{i}$ and $\delta$ are common knowledge. $\phi$ is a measure of the concentration of political preferences and represents how many voters of each group would change their preferred candidate following a marginal change in the policy platform of a candidate. ${ }^{17}$

As opposed to the standard median-voter models used by RRMR, in the probabilistic voting set-up, the intensity of preference of all voters matters for determining the political equilibrium and voters have idiosyncratic non-economic preferences for candidates. ${ }^{18}$ In such a framework, a low-income voter can support a low-tax candidate and a high-income voter support the high-tax candidate. By contrast, the RRMR-type models do not allow for voters to vote against the policy that maximizes their utility from income. Using the median voter model would yield obvious results since the median voter (if low-income, as often assumed) would benefit both form redistribution and from an increase in the diversity of goods.

The timing of the political game is as follows:

1. Both candidates announce simultaneously and non-cooperatively their political platform $\tau_{A}$ and $\tau_{B}$ (commitment is assumed to be perfect),

2. Realizations of $\sigma^{i}$ and $\delta$ are revealed (privately for the former, publicly for the latter),

3. Elections take place, and

4. The winning policy platform is implemented.

Remark 2. The political equilibrium tax rate is defined by:

$$
\underbrace{\frac{\partial U}{\partial I}\left(q_{0}^{*}\left(\widehat{I}^{L}(\tau)\right), Q^{*}\left(\widehat{I}^{L}(\tau)\right)\right)}_{\text {GAIN }}-\underbrace{\frac{\partial U}{\partial I}\left(q_{0}^{*}\left(\widehat{I}^{H}(\tau)\right), Q^{*}\left(\widehat{I}^{H}(\tau)\right)\right)}_{\text {LOSS }}=0 .
$$

\footnotetext{
${ }^{17}$ In the working paper version (Bourlès et al., 2014) we considered a group-specific dispersion parameter. Results are qualitatively unchanged.

${ }^{18}$ In this sense, ordinal preferences over tax rates are not enough for the probabilistic voting model to determine votes for policy platforms.
} 
Proof. See Appendix.

Equation (5) implicitly defines $\tau^{*}$ (and therefore $\widehat{I}^{L *}$ and $\widehat{I}^{H *}$ ) as the left hand part of equation (5) is decreasing in $\tau$. This condition is intuitive. To maximize the probability of winning, each candidate announces a tax rate such that her expected share of votes is maximized (and equal to one half at the symmetric equilibrium). At the equilibrium, $\tau$ is such that any deviation from this platform would cause a decrease in expected vote share. A marginal increase (resp. decrease) in the tax rate offered by one candidate leads to a gain

(resp. loss) of $\frac{\xi}{\phi} G A I N$ low-income voters and a loss (resp. gain) of $-\frac{\xi}{\phi} L O S S$ of high-income voters. The number of voters who switch candidates depends on two factors: $(i)$ the intensity of their individual preference for each candidate represented by $\phi$ (i.e., the number or swing voters in each group) and (ii) the effect on utility of a change in the tax rate: $\frac{\partial U}{\partial I} \cdot \frac{\partial \widehat{I}^{j}}{\partial \tau}$. At equilibrium, gains and losses compensate and no candidate has an incentive to deviate from the policy platform.

The impact of an increase in inequality (a decrease in $\theta$ for a given average income $\widetilde{I}$ ) is straightforward. Differentiating (5) with respect to $\theta$ gives $\frac{\partial \tau}{\partial \theta}<0$ as utility is concave. In other words, an increase in inequality should increase the equilibrium tax rate. Due to the concavity of the utility function, after an increase in inequality, low-income voters are more sensitive to changes in the tax rate than high-income voters. As a result, both candidates shift their policy platform to a higher tax rate. This result is in line with the standard textbook model of redistribution (see RRMR class of models, for instance). We now turn to the factor that may explain why redistribution did not increase in response to the substantial increase in inequality observed over the last decades: the increase in diversity.

\section{The effect of an increase in the number of varieties}

Now that we have described both the market and the political equilibria, we can analyze the effect on the equilibrium tax rate of an exogenous increase in the number of varieties. Let us 
first derive, using equation (5), a condition on the utility achieved at the equilibrium under which the equilibrium tax rate $\tau$ is decreasing with the number of varieties $n$. We will then try to relate it to underlying preferences.

As the left hand side of $(5)$ is decreasing in $\tau, \partial \tau^{*} / \partial n$ has the same sign as the following

$$
\frac{\partial^{2} U}{\partial n \partial I}\left(q_{0}^{*}\left(\widehat{I}^{L}(\tau)\right), Q^{*}\left(\widehat{I}^{L}(\tau)\right)\right)-\frac{\partial^{2} U}{\partial n \partial I}\left(q_{0}^{*}\left(\widehat{I}^{H}(\tau)\right), Q^{*}\left(\widehat{I}^{H}(\tau)\right)\right)
$$

and the following Lemma holds.

Lemma 1. The equilibrium tax rate is decreasing in the number of varieties $\left(\partial \tau^{*} / \partial n \leq 0\right)$ if

$$
\frac{\partial^{3} U}{\partial n \partial I^{2}}\left(q_{0}^{*}, Q^{*}\right) \geq 0
$$

i.e., that is if the marginal utility of money increases more with the number of varieties for richer agents.

Proof. See Appendix.

Condition (7) can be intuited as follows. If the marginal utility of income increases by the same amount for the swing voters of each group after an increase in the number of varieties, $n\left(\frac{\partial^{2} U\left(q_{0}^{*}\left(\widehat{I}^{L}(\tau)\right), Q^{*}\left(\widehat{I}^{L}(\tau)\right)\right)}{\partial n \partial I}=\frac{\partial^{2} U\left(q_{0}^{*}\left(\widehat{I}^{H}(\tau)\right), Q^{*}\left(\widehat{I}^{H}(\tau)\right)\right)}{\partial n \partial I}\right)$, then a marginal modification of the tax rate platform by one candidate is not profitable, as the number of voters who switch candidates exactly compensates. If, after an increase in $n$, the marginal utility of income increases more for high-income voters than for low-income ones, a marginal decrease in the tax rate becomes advantageous for a candidate as, everything else equal, it would attract more high-income voters to its policy platform than the resulting loss of low-income voters. Both candidates find this deviation advantageous and the equilibrium tax rate decreases as the number of varieties increases. ${ }^{19}$

\footnotetext{
${ }^{19}$ This effect is reinforced if low-income voters have more dispersed political preferences (Bourlès et al., 2014).
} 
Let us now understand how condition (7) is linked to individual preferences, that is how the welfare effect of an increase in the number of varieties varies with income.

Proposition 1. When taxes are used to finance redistribution, the equilibrium tax rate decreases in the number of varieties if, at the optimum,

$$
\frac{\partial^{3} U}{\partial n \partial I^{2}}=\frac{1-\rho}{\rho n} \frac{\partial^{2} Q^{*}}{\partial I^{2}}\left(Q^{*} U_{22}+U_{2}\right)+\frac{1-\rho}{\rho n}\left(\frac{\partial Q^{*}}{\partial I}\right)^{2}\left(Q^{*} U_{222}+2 U_{22}\right) \geq 0 .
$$

Assuming $R R A\left(q_{0}^{*}, Q^{*}\right) \leq 1$ and $R P\left(q_{0}^{*}, Q^{*}\right) \leq 2$ this holds when $\frac{\partial^{2} Q^{*}}{\partial I^{2}}>0$, that is under condition (3).

The sign of $\frac{\partial^{3} U\left(q_{0}^{*}, Q^{*}\right)}{\partial n \partial I^{2}}$ is a priori ambiguous and notably depends on the value of $\partial^{2} Q^{*} / \partial I^{2}$ (which is positive under condition (3)): a feature of non-homothetic preferences. $\partial^{2} Q^{*} / \partial^{2} I>$ 0 indicates that the share of an extra unit of income spent on good $Q$ is increasing in income (see Latzer and Mayneris, 2012 for a discussion of modeling non-homothetic preferences).

Conditions $R R A() \leq$.1 and $R P() \leq$.2 are typical in the literature. In our context, the first condition ensures that high-income consumers benefits more than low-income consumers from an increase in diversity (i.e. $\frac{\partial^{2} U}{\partial n \partial I}>0$, see equation (25) in the appendix). Put differently, marginal utility from income is increasing with the number of varieties. This condition of an index of relative risk aversion being lower than one is moreover consistent with the findings of Chetty (2006). In a model without uncertainty, as ours, Chetty (2006) shows that empirical evidence on labor supply is only consistent with a low decreasing rate of marginal utility of consumption, that corresponds coefficient of relative risk aversion lower than one.

Similarly, the second condition, that relative prudence is lower than 2 , is generally accepted. In particular, in portfolio management, it is a necessary condition for a second-order dominant shift in the return of a risky asset to increase its demand (Hadar and Seo, 1990; Choi et al., 2001), which seems reasonable. Eeckhoudt et al. (2009), provide a context-free interpretation of this condition in terms of preferences between lotteries.

Note that non-homotheticity, $R R A() \leq$.1 and $R P() \leq$.2 are sufficient conditions for 
(7). In particular, (7) may hold even when relative prudence is greater than 2 , if $\partial^{2} Q^{*} / \partial^{2} I$ is high enough. Therefore, more generally than the case from Proposition 1, if preferences are "non-homothetic enough" in favor of composite good $Q$, an increase in the number of varieties $n$ decreases the equilibrium tax rate $\tau^{*}$.

In this section, we have characterized the conditions under which an increase in the diversity of goods could have shifted the equilibrium level of redistribution toward the policy preferences of high-income agents. The channel depends on how the relative marginal utility from income of high-income and low-income agents are affected. In a voting game, this determines the relative number of agents in the two groups who would change their vote if a marginal change in the policy platform is implemented. If the marginal utility of the highincome agent increases sufficiently relatively to the low-income agents, it is advantageous for both candidates to deviate and decrease the tax rate. We show this is the case if preferences are sufficiently non-homothetic. To our knowledge, this is the first paper to highlight the increase in goods diversity and uneven gains from such an increase as a possible explanation for the fact that redistribution has not kept up with the rise of inequalities over the last decades.

\section{The case of public goods}

It has recently been documented that public investment in infrastructure or schools in US is at its lowest level since the post second war period (see Financial Times, 2013, for instance). The aim of this section is to analyze to what extend the mechanism described above can also explain this phenomenon. To do so, we introduce a public good in our model and study the impact of an increase in private goods diversity. We denote by $G$ the per capita quantity of public good provided by the government. We describe voters' preferences by a utility function $U\left(q_{0}, Q, G\right)$, increasing and concave in all three arguments (that is $U_{1}>0, U_{2}>0, U_{3}>0$, $U_{11} \leq 0, U_{22} \leq 0$ and $\left.U_{33} \leq 0\right)$. As usual in the literature, we assume that preferences are 
separable in $G$. To keep the model tractable, we moreover assume away pure redistribution: agents vote for a tax rate that only finances public good provision. As in the previous model, we assume two income classes indexed by $j=\{L ; H\}$ with respective incomes $I^{L}$ and $I^{H}\left(>I^{L}\right)$ and respective proportions $\alpha^{L}$ and $\alpha^{H}$; and that only high-income agents pay the tax (to represent progressivity). After-tax incomes are therefore written $\widehat{I}^{H}(\tau)=(1-\tau) I^{H}$ and $\widehat{I}^{L}(\tau)=I^{L}$, and the government's budget constraint is $P^{G} G=\tau \alpha^{H} I^{H}$ with $P^{G}$ the price of the public good. Agents vote on the tax rate $\tau$ as in the previous model.

Remark 3. The political equilibrium tax rate is defined by:

$$
\frac{1}{P^{G}}\left(\frac{\partial U}{\partial G}(G)\right)-\frac{\partial U}{\partial I}\left(q_{0}^{*}\left(\widehat{I}^{H}(\tau)\right), Q^{*}\left(\widehat{I}^{H}(\tau)\right)\right)=0
$$

Proof. See Appendix.

Equation (9) implicitly defines $\tau^{*}$ (and therefore $\widehat{I}^{L *}$ and $\widehat{I}^{H *}$ ) as the left hand size of equation (9) is decreasing in $\tau . \partial \tau^{*} / \partial n$ is then of the sign of $-\frac{\partial^{2} U}{\partial I \partial n}$ and the next proposition holds.

Proposition 2. When taxes are used to finance the provision of a public good, the equilibrium tax rate is decreasing in the number of varieties $\left(\partial \tau^{*} / \partial n \leq 0\right)$ if and only if the marginal utility of money increases with the number of varieties, that is if and only if $R R A\left(q_{0}^{*}, Q^{*}, G^{*}\right) \leq 1$.

The condition for $\partial \tau^{*} / \partial n$ is much less restrictive than for the case of redistribution. It can be intuited as follows. If an increase in the number of varieties increases the marginal utility of income, it makes the public good less valuable relative to private consumption for both income groups. As a result, a marginal deviation (decrease) of the tax rate attracts more high-income voters than the resulting loss of low-income voters whose marginal utility from public goods remains unchanged. Both candidates find this deviation advantageous and the equilibrium tax rate decreases as the number of varieties increases. This effect would be 
reinforced if low-income voters also bear the financing of public good provision (i.e. also pay taxes) since they would then also benefit from an increase in private consumption.

\section{Empirical investigation}

In this section, we provide some empirical evidence that supports our theoretical conclusions. We proceed in two steps. First, using macro data over a panel of OECD countries, we investigate the political implications of rising goods diversity. Here we are able to demonstrate that within-country variation in goods diversity is robustly negatively correlated with withincountry variation in the tax rates levied on middle income groups across OECD countries, as our model predicts. Second, we analyze survey data to investigate the micro-political foundations of our probabilistic voting model. Namely, we are able to demonstrate that individuals are more likely to identify themselves as "right" on the political spectrum (less pro-poor policies) when the diversity of goods in their country increases. Moreover, the effect of an increase in goods diversity is significantly positive only for the relatively rich within the OECD countries for which we have the survey data, which supports an important mechanism of our theoretical model.

\section{Country-level analysis}

In this sub-section, we investigate the extent to which increases in the diversity of goods are correlated with reductions in the fiscal pressure on the politically relevant segments of the income distribution.

Data and empirical strategy. The major difficulty of such an analysis is to find a proxy for the diversity of goods. In order to compute the number of varieties available to consumers, we use the methodology developed by Broda and Weintein (2006). Using a 6 digit dataset for trade aggregated at the product level we consider as a variety any imported product line from a given country. In other words, the same product imported from two different countries is 
considered as two distinct varieties. The sum of imputed product/country pairs corresponds to foreign varieties available to domestic consumers. For domestic varieties we simply consider the number of exported product types for a given country. We build the variety measure from the data compiled by Gaulier and Zignago (2010), who built their dataset from UN COMTRADE data. As shown in Figure 1, on average across the OECD countries, the variety of goods has increased by more than $20 \%$ since 1995. Our main measure, variety, considers the total variety of goods in each country-year, but we also consider a measure which isolates variety in consumables, variety_c, as a robustness check. ${ }^{20}$

Our baseline analysis considers several proxies for fiscal pressure. First, using data from the OECD, we use the income tax rates payed by the middle income group income in the national income distribution as our baseline dependent variable. Specifically, we look at the average income tax rate payed by the average income earner. As a robustness check, we also consider the income tax rate payed by the upper-middle income group, as they may have more de facto influence on policy platforms than the middle income group. Also from the OECD, we use the average tax rate faced by the income level that is 1.33 times the average income level as a measure of the fiscal pressure on the upper-middle income group. The tax rate data from the OECD starts from 2000. We consider the income tax rate faced by middle income earners since they are the most politically relevant group, for both redistribution policy and public goods provision policy. Within the context of the probabilistic voting model, the "swing voters" are most likely to come from the middle income groups. ${ }^{21}$ Nevertheless, we also consider fiscal indexes that take top tax rates into account.

Furthermore, we consider two well-known indexes as proxies for fiscal pressure and progressiveness of the tax system to test for robustness. First, we use the index of Fiscal Freedom

\footnotetext{
${ }^{20}$ The measure that isolates consumables takes out raw materials not used for home production, intermediate goods and industrial inputs. Specifically, we dropped categories 25, 26, 27, 84, and 86.

${ }^{21}$ Additionally, using the top income tax rate as the dependent variable would be problematic for another reason. Top income voters are much more mobile across tax jurisdictions and the decrease in the top tax rate observed over the last decades may be more related to fiscal competition stories. More generally, political equilibria for the top tax rate may follow a quite different political logic than tax rates for the rest of the population.
} 


\section{Standardized variation for key variables within Denmark}
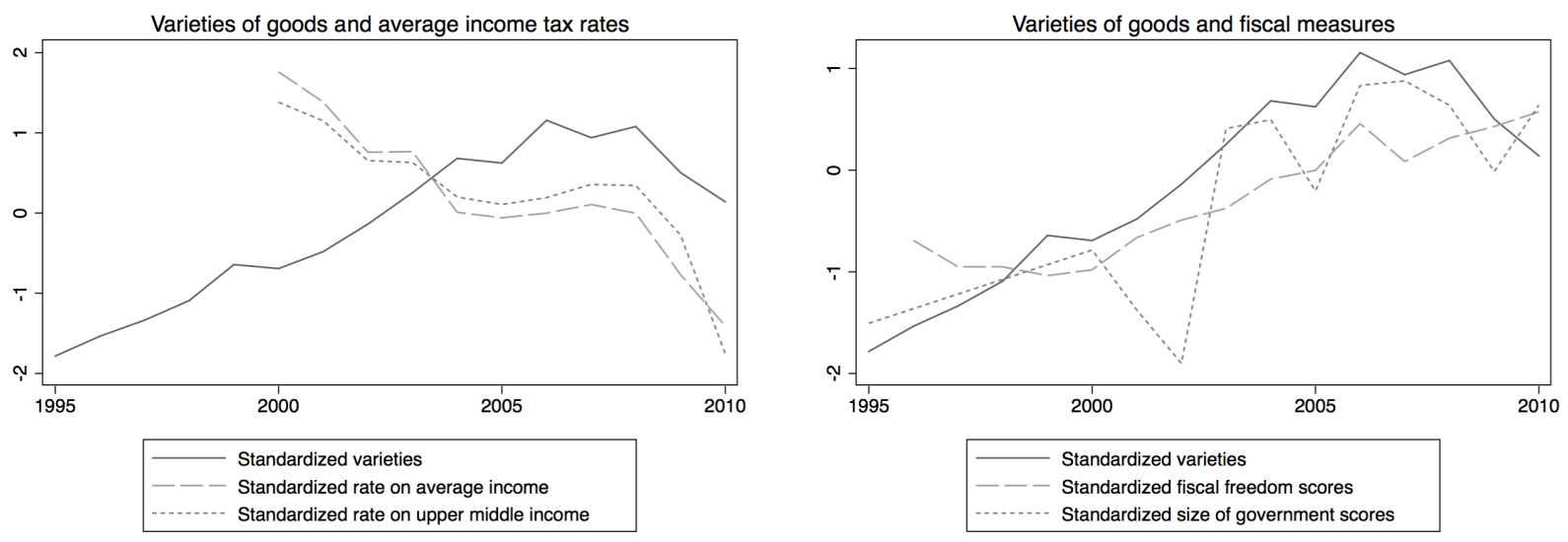

Figure 2: Within country standardized variation in the key variables for Denmark. The average income tax rates are in the left-hand panel and the fiscal freedom scores are are in the right-hand side panel.

from the Heritage Foundation (Heritage Foundation, 2016), which is a sub-index of their index of Economic Freedom. It is an equally weighted index of the total tax revenue as a percentage of GDP, the top rate on individual income, and the top rate on corporate income. The index ranges between 0 and 100, where higher scores represent higher degrees of fiscal freedom. Apart from its clear relevance as a proxy for fiscal pressure, the Fiscal Freedom index starts from 1995, allowing us to extend the panel regression analysis over a slightly longer time period. Second, we use the index of the Size of Government from the Fraser Institute, which is a sub-index of their Economic Freedom of the World Index. The index is composed of general government consumption as a percentage of total consumption, government investment as a percentage of total investment, the top marginal tax rate and the income threshold for it, as well as transfers and subsidies as a percentage of GDP. The index ranges between 0 and 10, where higher scores correspond to a smaller governmental presence in the private economy. Figure 2 demonstrates how our measures of fiscal pressure co-vary over time with varieties of goods for Denmark. The figure presents the within-country standardized variation for the average tax rates in the left-hand side and for the fiscal scores of the Heritage Foundation and the Fraser Institute in the right-hand side. 
Table 1: Summary Statistics - Macro Data

\begin{tabular}{llllll}
\hline Variable & Obs. & Mean & Std. Dev. & Min. & Max. \\
\hline Average tax rate for the average income & 377 & 36.845 & 10.563 & 12.681 & 57.104 \\
Average tax rate for 133\% average income & 377 & 39.601 & 10.485 & 16.57 & 60.442 \\
total variety $(1000$ 's) & 377 & 90.578 & 28.076 & 33.649 & 162.363 \\
variety in consumables $(1000 ' s)$ & 377 & 78.116 & 24.285 & 29.369 & 140.44 \\
Per capita GDP $(\$ 1000$ 's) & 377 & 31.079 & 10.498 & 8.747 & 66.363 \\
Gini coefficient & 312 & 44.748 & 5.269 & 33.909 & 61.685 \\
HF fiscal freedom index & 377 & 60.291 & 13.087 & 29.8 & 89.5 \\
Fl size of government index & 377 & 5.480 & 1.250 & 2.565 & 8.312 \\
& & & & & \\
\hline
\end{tabular}

Throughout our empirical analysis, we also control for income level and income inequality. Income level is approximated by GDP per capita, expressed in current prices in 1000's of US dollars, from the World Development Indicators (World Bank, 2016). To control for income inequality, we draw upon the Standardized World Inequality Indicators Database (SWIID), constructed and maintained by Frederick Solt (Solt, 2009). ${ }^{22}$ We report results that control for the gross Gini coefficients (before taxes and transfers). It is important to control for the level of inequality as it is the principle theoretical determinant of redistributive fiscal expenditures in the classic workhorse models, such as the RRMR class of models.

Summary statistics from our baseline sample are reported in Table 1. ${ }^{23}$ Tables 2 and 3 present results from regressions that take the following general form:

$$
\text { fiscal_pressure }_{i, t}=\alpha+\beta \text { variety }_{i, t-1}+\Gamma^{\prime} X_{i, t-1}+\eta_{i}+\eta_{t}+u_{i, t},
$$

where the $\eta_{t}$ 's denote a full set of time effects that capture common shocks to the degree of fiscal pressure ${ }^{24}$, the $\eta_{i}$ 's denote a full set of country dummies that capture any time-invariant

\footnotetext{
${ }^{22}$ The SWIID combines the Luxembourg Income Study with the World Inequality Indicators Database and standardizes the measurements across the two databases yielding a cross-national panel that is significantly enlarged from the individual databases.

${ }^{23}$ Countries included in the cross-country analysis include the following: Australia, Austria, Belgium, Canada, Czech Republic, Denmark, Finland, France, Germany, Greece, Hungary, Iceland, Ireland, Italy, Japan, Mexico, Netherlands, New Zealand, Norway, Poland, Portugal, Slovakia, South Korea, Spain, Sweden, Switzerland, Turkey, United Kingdom, and the United States. The panel runs from $2000-2012$.

${ }^{24}$ For example, shocks to global political ideology or to the degree of global fiscal competition due to transportation technologies may have exerted downward pressure on tax rates that are picked up by this
} 
Table 2: Average Income Tax Rate - Total Variety

\begin{tabular}{|c|c|c|c|c|c|c|c|c|}
\hline & \multicolumn{4}{|c|}{ Variety in levels } & \multicolumn{4}{|c|}{ Variety in logs } \\
\hline & (1) & $(2)$ & (3) & (4) & (5) & (6) & $(7)$ & (8) \\
\hline \multicolumn{9}{|c|}{ Panel A. DV: Average tax rate for the average income } \\
\hline variety $_{t-1}$ & $\begin{array}{l}-0.0762^{* *} \\
(0.037)\end{array}$ & $\begin{array}{l}-0.0347^{* *} \\
(0.015)\end{array}$ & $\begin{array}{l}-0.0671^{*} \\
(0.033)\end{array}$ & $\begin{array}{l}-0.0442^{* * *} \\
(0.014)\end{array}$ & $\begin{array}{l}-6.6214^{* *} \\
(2.754)\end{array}$ & $\begin{array}{l}-3.4614^{* *} \\
(1.296)\end{array}$ & $\begin{array}{l}-5.6831^{* *} \\
(2.476)\end{array}$ & $\begin{array}{l}-4.0202^{* * *} \\
(1.283)\end{array}$ \\
\hline average tax rate $_{t-1}$ & & $\begin{array}{l}0.7191^{* * *} \\
(0.050)\end{array}$ & & $\begin{array}{l}0.6712^{* * *} \\
(0.060)\end{array}$ & & $\begin{array}{l}0.7130 * * * \\
(0.051)\end{array}$ & & $\begin{array}{l}0.6668 * * * \\
(0.061)\end{array}$ \\
\hline GDP per capita ${ }_{t-1}$ & & & $\begin{array}{l}-0.1545^{*} \\
(0.088)\end{array}$ & $\begin{array}{l}0.0081 \\
(0.034)\end{array}$ & & & $\begin{array}{l}-0.1558 * \\
(0.088)\end{array}$ & $\begin{array}{l}0.0074 \\
(0.033)\end{array}$ \\
\hline Gini $t-1$ & & & $\begin{array}{l}-0.0545 \\
(0.072)\end{array}$ & $\begin{array}{l}-0.0249 \\
(0.037)\end{array}$ & & & $\begin{array}{l}-0.0524 \\
(0.075)\end{array}$ & $\begin{array}{l}-0.0231 \\
(0.039)\end{array}$ \\
\hline constant & $\begin{array}{l}43.7058 * * * \\
(2.892)\end{array}$ & $\begin{array}{l}13.0296 * * * \\
(2.685)\end{array}$ & $\begin{array}{l}50.6231 * * * \\
(5.240)\end{array}$ & $\begin{array}{l}16.6776^{* * *} \\
(3.323)\end{array}$ & $\begin{array}{l}112.2100 * * * \\
(31.474)\end{array}$ & $\begin{array}{l}50.2390 * * * \\
(15.454)\end{array}$ & $\begin{array}{l}109.5306 * * * \\
(28.330)\end{array}$ & $\begin{array}{l}59.2721^{* * *} \\
(15.091)\end{array}$ \\
\hline Country \& year FE's & Yes & Yes & Yes & Yes & Yes & Yes & Yes & Yes \\
\hline $\mathrm{N}$ & 377 & 348 & 341 & 312 & 377 & 348 & 341 & 312 \\
\hline Countries & 29 & 29 & 29 & 29 & 29 & 29 & 29 & 29 \\
\hline within $\mathrm{R}^{2}$ & 0.1096 & 0.6011 & 0.1518 & 0.5378 & 0.1194 & 0.6057 & 0.1588 & 0.5429 \\
\hline \multicolumn{9}{|c|}{ Panel B. DV: Average tax rate for income $133 \%$ of average income } \\
\hline variety $_{t-1}$ & $\begin{array}{l}-0.0712^{* *} \\
(0.033)\end{array}$ & $\begin{array}{l}-0.0410 * \\
(0.020)\end{array}$ & $\begin{array}{l}-0.0590 * \\
(0.031)\end{array}$ & $\begin{array}{l}-0.0491^{* * *} \\
(0.016)\end{array}$ & $\begin{array}{l}-7.7323 * * \\
(3.023)\end{array}$ & $\begin{array}{l}-4.6232 * * \\
(2.086)\end{array}$ & $\begin{array}{l}-6.8875^{* *} \\
(2.647)\end{array}$ & $\begin{array}{l}-5.2852 * * \\
(2.006)\end{array}$ \\
\hline average tax rate $_{t-1}$ & & $\begin{array}{l}0.6802 * * * \\
(0.064)\end{array}$ & & $\begin{array}{l}0.6175^{* * *} \\
(0.076)\end{array}$ & & $\begin{array}{l}0.6637^{* * *} \\
(0.069)\end{array}$ & & $\begin{array}{l}0.5996 * * * \\
(0.078)\end{array}$ \\
\hline GDP per capita ${ }_{t-1}$ & & & $\begin{array}{l}-0.1957^{* *} \\
(0.080)\end{array}$ & $\begin{array}{l}0.0126 \\
(0.036)\end{array}$ & & & $\begin{array}{l}-0.1967^{* *} \\
(0.082)\end{array}$ & $\begin{array}{l}0.0095 \\
(0.033)\end{array}$ \\
\hline Gini $t-1$ & & & $\begin{array}{l}-0.0856 \\
(0.074)\end{array}$ & $\begin{array}{l}-0.0280 \\
(0.051)\end{array}$ & & & $\begin{array}{l}-0.0775 \\
(0.076)\end{array}$ & $\begin{array}{l}-0.0244 \\
(0.053)\end{array}$ \\
\hline constant & $\begin{array}{l}46.1294 * * * \\
(2.528)\end{array}$ & $\begin{array}{l}15.9461^{* * *} \\
(4.188)\end{array}$ & $\begin{array}{l}55.4066^{* * *} \\
(5.750)\end{array}$ & $\begin{array}{l}20.1367 * * * \\
(5.348)\end{array}$ & $\begin{array}{l}127.4226 * * * \\
(34.628)\end{array}$ & $\begin{array}{l}66.0617^{* *} \\
(25.756)\end{array}$ & $\begin{array}{l}128.2381^{* * * *} \\
(31.807)\end{array}$ & $\begin{array}{l}77.0078 * * * \\
(25.373)\end{array}$ \\
\hline Country \& year FE's & Yes & Yes & Yes & Yes & Yes & Yes & Yes & Yes \\
\hline $\mathrm{N}$ & 377 & 348 & 341 & 312 & 377 & 348 & 341 & 312 \\
\hline Countries & 29 & 29 & 29 & 29 & 29 & 29 & 29 & 29 \\
\hline within $\mathrm{R}^{2}$ & 0.1259 & 0.5851 & 0.1941 & 0.5366 & 0.1526 & 0.5950 & 0.2187 & 0.5499 \\
\hline
\end{tabular}

country characteristics that affect the degree of fiscal pressure, and $u_{i, t}$ is an error term that captures all other factors, with $E\left(u_{i, t}\right)=0$ for all countries $i$ and all time periods $t$. In all of the results we report standard errors that have been clustered at the country level.

Results. The results reported in Tables 2 and 3 are from regressions that have lagged the explanatory variables by one period. In some specifications we also include a lagged dependent variable to control for dynamic effects. All regressions include country and year fixed effects and have clustered standard errors at the country level. In table 2, the top fixed effect. 
panel takes as dependent variable the average tax rate faced by the average income earner, while the bottom panel considers that faced by earners with 1.33 times the average income. Columns $1-4$ use variety of goods in levels as the primary explanatory variable, whereas columns $5-8$ use variety in logs. Our fixed effects panel regression specifications estimate a negative impact of goods variety that is substantial and statistically significant. From panel A, column 4, for example, a one standard deviation increase in the variety of goods is associated with a 1.24 percentage point reduction in the average tax rate payed by the average income earner (about 0.12 standard deviation reduction). The result is robust to estimation with variety in logs, as well as to estimation of the effect on the upper-middle income tax rate (in panel B). ${ }^{25}$ The results also confirm previous findings that the level of inequality is not a significant determinant of fiscal outcomes. An online appendix also reports the analogue of Table 2 using a measure of goods diversity that focuses on consumable goods.

We also present some evidence using some well known indexes of fiscal pressure. In panel A, Table 3 presents results using the Fiscal Freedom sub-index of the Heritage Foundation's index of Economic Freedom. Another highly relevant proxy for fiscal pressure is the Size of Government index from the Fraser Institute's Economic Freedom of the World Index, which we use as the dependent variable in the results presented in panel B of Table 3 . Both measures take higher values when the governmental fiscal policy plays a smaller role in the private economy, so we expect positive correlations between goods variety and the indexes.

Indeed, we estimate positive and statistically significant correlations between the variety of goods and freedom from fiscal pressure using these two indexes, in line with our theoretical predictions and the results from Table 2. While the correlation with Fiscal Freedom Index is robust to the inclusion of the lagged dependent variable, the correlation with the Size of Government is not statistically significant when we include its lag as a regressor. As

\footnotetext{
${ }^{25}$ We do not make any causal claims. While we have lagged the explanatory variables, it is possible that anticipated future period reductions in fiscal pressure could plausibly increase current levels of goods variety as manufacturers and retailers anticipate a future increase in consumer disposable income. An explicit demonstration that the causal relationship runs from goods variety to future fiscal pressure is beyond the scope of our empirical investigation, which provides a simple exploration into whether the correlations are consistent with our theoretical intuitions.
} 
Table 3: Fiscal Indexes - Total Variety

\begin{tabular}{|c|c|c|c|c|c|c|c|c|}
\hline & \multicolumn{4}{|c|}{ Variety in levels } & \multicolumn{4}{|c|}{ Variety in logs } \\
\hline & $(1)$ & $(2)$ & (3) & (4) & (5) & $(6)$ & (7) & (8) \\
\hline \multicolumn{9}{|c|}{ Panel A. DV: Heritage Foundation Fiscal Freedom Index } \\
\hline variety $_{t-1}$ & $\begin{array}{l}0.4009 * * * \\
(0.124)\end{array}$ & $\begin{array}{l}0.1387^{* *} \\
(0.059)\end{array}$ & $\begin{array}{l}0.4057^{* * *} \\
(0.146)\end{array}$ & $\begin{array}{l}0.1747 * * \\
(0.077)\end{array}$ & $\begin{array}{l}33.2289 * * * \\
(10.392)\end{array}$ & $\begin{array}{l}10.6089 * * * \\
(3.758)\end{array}$ & $\begin{array}{l}33.1403 * * \\
(12.041)\end{array}$ & $\begin{array}{l}12.8555^{* *} \\
(4.821)\end{array}$ \\
\hline fiscal freedom $_{t-1}$ & & $\begin{array}{l}0.7357^{* * *} \\
(0.035)\end{array}$ & & $\begin{array}{l}0.7229 * * * \\
(0.034)\end{array}$ & & $\begin{array}{l}0.7310 * * * \\
(0.037)\end{array}$ & & $\begin{array}{l}0.7176 * * * \\
(0.036)\end{array}$ \\
\hline GDP per capita $t-1$ & & & $\begin{array}{l}-0.4105 \\
(0.350)\end{array}$ & $\begin{array}{l}-0.0372 \\
(0.094)\end{array}$ & & & $\begin{array}{l}-0.3827 \\
(0.352)\end{array}$ & $\begin{array}{l}-0.0299 \\
(0.098)\end{array}$ \\
\hline Gini $t-1$ & & & $\begin{array}{l}0.0834 \\
(0.168)\end{array}$ & $\begin{array}{l}0.0494 \\
(0.067)\end{array}$ & & & $\begin{array}{l}0.0641 \\
(0.174)\end{array}$ & $\begin{array}{l}0.0440 \\
(0.069)\end{array}$ \\
\hline constant & $\begin{array}{l}24.1700 * * \\
(9.386)\end{array}$ & $\begin{array}{l}4.5596 \\
(4.357)\end{array}$ & $\begin{array}{l}35.1012 * \\
(18.702)\end{array}$ & $\begin{array}{l}1.0213 \\
(6.821)\end{array}$ & $\begin{array}{l}-314.2793^{* *} \\
(118.631)\end{array}$ & $\begin{array}{l}-103.3112^{* *} \\
(41.519)\end{array}$ & $\begin{array}{l}-303.8414^{* *} \\
(137.411)\end{array}$ & $\begin{array}{l}-129.1209 * * \\
(53.955)\end{array}$ \\
\hline Country \& year FE's & Yes & Yes & Yes & Yes & Yes & Yes & Yes & Yes \\
\hline $\mathrm{N}$ & 492 & 484 & 456 & 448 & 492 & 484 & 456 & 448 \\
\hline Countries & 29 & 29 & 29 & 29 & 29 & 29 & 29 & 29 \\
\hline within $\mathrm{R}^{2}$ & 0.4239 & 0.7754 & 0.4273 & 0.7594 & 0.4350 & 0.7756 & 0.4375 & 0.7593 \\
\hline \multicolumn{9}{|c|}{ Panel B. DV: Fraser Institute Size of Government Index } \\
\hline variety $_{t-1}$ & $\begin{array}{l}0.0336 * * \\
(0.015)\end{array}$ & $\begin{array}{l}0.0030 \\
(0.005)\end{array}$ & $\begin{array}{l}0.0340 * * \\
(0.014)\end{array}$ & $\begin{array}{l}0.0024 \\
(0.005)\end{array}$ & $\begin{array}{l}2.7814^{* *} \\
(1.324)\end{array}$ & $\begin{array}{l}0.2231 \\
(0.383)\end{array}$ & $\begin{array}{l}2.8513^{* *} \\
(1.289)\end{array}$ & $\begin{array}{l}0.2123 \\
(0.427)\end{array}$ \\
\hline size of government $t_{t-1}$ & & $\begin{array}{l}0.6719 * * * \\
(0.040)\end{array}$ & & $\begin{array}{l}0.6442 * * * \\
(0.048)\end{array}$ & & $\begin{array}{l}0.6717^{* * *} \\
(0.040)\end{array}$ & & $\begin{array}{l}0.6429 * * * \\
(0.048)\end{array}$ \\
\hline GDP per capita $t_{t-1}$ & & & $\begin{array}{l}0.0565^{* *} \\
(0.025)\end{array}$ & $\begin{array}{l}0.0100 \\
(0.011)\end{array}$ & & & $\begin{array}{l}0.0572^{* *} \\
(0.025)\end{array}$ & $\begin{array}{l}0.0102 \\
(0.011)\end{array}$ \\
\hline Gini $t-1$ & & & $\begin{array}{l}0.0005 \\
(0.030)\end{array}$ & $\begin{array}{l}-0.0009 \\
(0.011)\end{array}$ & & & $\begin{array}{l}-0.0005 \\
(0.030)\end{array}$ & $\begin{array}{l}-0.0010 \\
(0.012)\end{array}$ \\
\hline constant & $\begin{array}{l}2.1108 \\
(1.273)\end{array}$ & $\begin{array}{l}1.4924 * * * \\
(0.489)\end{array}$ & $\begin{array}{l}0.0971 \\
(2.132)\end{array}$ & $\begin{array}{l}1.1007 \\
(0.765)\end{array}$ & $\begin{array}{l}-26.1394 * \\
(15.092)\end{array}$ & $\begin{array}{l}-0.7727 \\
(4.375)\end{array}$ & $\begin{array}{l}-28.9020^{*} \\
(14.565)\end{array}$ & $\begin{array}{l}-0.6721 \\
(4.803)\end{array}$ \\
\hline Country \& year FE's & Yes & Yes & Yes & Yes & Yes & Yes & Yes & Yes \\
\hline $\mathrm{N}$ & 377 & 348 & 341 & 312 & 377 & 348 & 341 & 312 \\
\hline Countries & 29 & 29 & 29 & 29 & 29 & 29 & 29 & 29 \\
\hline within $\mathrm{R}^{2}$ & 0.3710 & 0.6858 & 0.4221 & 0.6701 & 0.3769 & 0.6858 & 0.4300 & 0.6702 \\
\hline \multicolumn{9}{|c|}{$\begin{array}{l}\text { Notes: } *, * *, \text { and } * * * \text { indicate significance at } 10,5 \text {, and } 1 \% \text { levels, respectively. In all regressions, standard errors are } \\
\text { clustered at the country level, over a panel of OECD countries, starting from } 1995 \text { in Panel A and } 2000 \text { in Panel B. Fiscal } \\
\text { Freedom measure is increasing in fiscal freedom, denoting less fiscal pressure, and is from the Heritage Foundation. The } \\
\text { Size of Government index is taken from the Fraser Institute and is also increasing freedom from fiscal pressure. The variety } \\
\text { of goods data was composed by the authors from Comtrade data. GDP per capita data is from the World Development } \\
\text { Indicators and reported in 1000's of current year US dollars. The Gini coefficient is a measure of pre-tax income inequality } \\
\text { that has been standardized across several common sources. }\end{array}$} \\
\hline
\end{tabular}

an index as broad as the Size of Government Index may be relatively slow moving within countries, it is not surprising that the lagged variable dominates in these specifications. An online appendix also reports the analogue of Table 3 using our alternative measure of goods diversity that focuses on the variety of consumables. Moreover, the correlations estimated in Table 3 provide reassuring support for our baseline result in panel A of Table 2, that within country variation in the variety of goods is negatively correlated with within country variation in the equilibrium degree of fiscal pressure on the private economy. 


\section{Micro-political foundations}

Here we investigate one of the assumptions embedded in our probabilistic voting model. We use survey responses from OECD countries pooled across the last four waves of the World Values Survey and the European Values Survey (WVS/EVS) to investigate the extent to which an increase in the variety of goods affects the political preferences of survey respondents. ${ }^{26}$ Moreover, we further investigate the extent to which the impact of greater goods variety on political preferences was stronger for the relatively rich, as hypothesized in our theory.

Data and empirical strategy. To approximate the political preferences of survey participants, we consider responses to a question that inquires about where on the political spectrum respondents place themselves. The relevant question, denoted political_position, asks respondents:

In political matters, people talk of "the left" and "the right". How would you place your views on this scale, generally speaking?

Respondents must then choose a number between 1 and 10, where 1 is labeled as "Left" and 10 is labeled as "Right", so the political_position variable takes higher values for more politically conservative individuals. We believe that looking at a variable that captures the overall political leaning of individuals is the most relevant for evaluating our theoretical hypotheses. The identifying assumption is that the left-right political spectrum corresponds most closely to fiscal preferences. ${ }^{27}$ The "Left" is generally associated with pro-poor policies in terms of public goods provision or pure redistribution.

\footnotetext{
${ }^{26}$ The waves were from 1994 - 1998, 1999 - 2004, 2005 - 2009, and 2010 - 2014, respectively. Unfortunately, the WVS/EVS surveys are available only for 22 of the 29 countries that are included in our country level investigation. Countries that are covered include the following: Australia, Canada, Czech Republic, Finland, France, Germany, Greece, Hungary, Italy, Japan, Mexico, Netherlands, New Zealand, Norway, Poland, Slovakia, South Korea, Spain, Sweden, Switzerland, Turkey, and the United States.

${ }^{27}$ There are some other variables in the WVS/EVS that we also considered. In particular, one question asks respondents about their views on income inequality. While interesting, the question frames preferences for inequality in terms of how less/more inequality affects peoples' incentives to work, rather than as a situation that government should correct though taxation and redistribution.
} 
Table 4: Summary Statistics - World Values Survey Data

\begin{tabular}{lcclll}
\hline Variable & Obs. & Mean & Std. Dev. & Min. & Max. \\
\hline political position & 62153 & 5.519 & 2.178 & 1 & 10 \\
income decile & 62153 & 4.829 & 2.453 & 1 & 10 \\
not poor & 62153 & 0.666 & 0.473 & 0 & 1 \\
unemployed & 62153 & 0.079 & 0.270 & 0 & 1 \\
male & 62103 & 0.501 & 0.500 & 0 & 1 \\
variety (1000's) & 62153 & 95.217 & 30.263 & 46.630 & 158.650 \\
GDP per capita (\$1000's) & 62153 & 26.023 & 10.577 & 9.369 & 48.192 \\
Gini coefficient & 60166 & 43.685 & 5.1528 & 31.934 & 55.495 \\
\hline
\end{tabular}

The WVS/EVS questionnaire also includes socioeconomic and demographic information. We use information about reported income decile to construct a binary class variable that separates the lowest class from the middle, upper-middle and upper classes. Specifically, we generate a binary variable not_poor that takes value one for individuals who report themselves to be in decile 4 or higher. ${ }^{28}$ As our theory distinguishes the effect of an increase in variety on political preferences between poor and not poor segments of the population, we investigate the extent to which the empirical impact of greater goods diversity is heterogenous across these broad income classes. We also control for individuals' employment status, gender, highest level of attained education, and age. At the contextual level, in addition to looking at the variety of goods, we also control for national income levels (using GDP per capita) and income inequality (using the Gini coefficient).

Summary statistics of the data used in the micro-political foundation investigation are reported in Table 4. The specification of most interest for us takes the following form:

$$
\begin{gathered}
\text { political_position }_{i, j, t}=\alpha+\beta_{1} \text { variety }_{j, t}+\beta_{2} \text { not_poor }_{i, j, t}+\beta_{3} \text { variety }_{j, t} \times \text { not_poor }_{i, j, t} \\
+\Gamma_{1}^{\prime} X_{j, t}+\Gamma_{2}^{\prime} Z_{i, j, t}+\eta_{j}+\eta_{t}+u_{i, j, t},
\end{gathered}
$$

\footnotetext{
${ }^{28}$ Results are qualitatively similar, with statistically significant interaction terms, when we estimate models with other cut-offs for the "not poor" group. We have also simply interacted the raw income decile variable with variety of goods. The effect of an increase in varieties becomes statistically significantly positive at around the fifth income decile. We thank an anonymous referee for suggesting these regressions, the results of which are available upon request.
} 
Table 5: Evidence from Survey Data - All waves of WVS

\begin{tabular}{|c|c|c|c|c|c|c|c|c|}
\hline \multirow[b]{3}{*}{ political position } & \multicolumn{8}{|c|}{ Linear Regression } \\
\hline & \multicolumn{4}{|c|}{ Variety in levels } & \multicolumn{4}{|c|}{ Variety in logs } \\
\hline & (1) & $(2)$ & (3) & (4) & (5) & (6) & (7) & (8) \\
\hline variety & $\begin{array}{l}0.0082^{*} \\
(0.004)\end{array}$ & $\begin{array}{l}0.0056 \\
(0.004)\end{array}$ & $\begin{array}{l}0.0064 \\
(0.006)\end{array}$ & $\begin{array}{l}-0.0013 \\
(0.005)\end{array}$ & $\begin{array}{l}0.7276^{*} \\
(0.371)\end{array}$ & $\begin{array}{l}0.4927 \\
(0.387)\end{array}$ & $\begin{array}{l}0.5199 \\
(0.478)\end{array}$ & $\begin{array}{l}0.1822 \\
(0.367)\end{array}$ \\
\hline not poor & & $\begin{array}{l}-0.3532 * \\
(0.179)\end{array}$ & $\begin{array}{l}-0.3601^{*} \\
(0.183)\end{array}$ & $\begin{array}{l}-0.1532 \\
(0.157)\end{array}$ & & $\begin{array}{l}-1.7147^{* *} \\
(0.739)\end{array}$ & $\begin{array}{l}-1.7816^{* *} \\
(0.749)\end{array}$ & $\begin{array}{l}-1.2766^{*} \\
(0.672)\end{array}$ \\
\hline not poor $\times$ variety & & $\begin{array}{l}0.0041^{* * *} \\
(0.001)\end{array}$ & $\begin{array}{l}0.0042^{* * *} \\
(0.002)\end{array}$ & $\begin{array}{l}0.0032 * * \\
(0.001)\end{array}$ & & $\begin{array}{l}0.3877^{* *} \\
(0.157)\end{array}$ & $\begin{array}{l}0.4035^{* *} \\
(0.159)\end{array}$ & $\begin{array}{l}0.3175^{* *} \\
(0.144)\end{array}$ \\
\hline GDP per capita & & & $\begin{array}{l}-0.0293 * \\
(0.017)\end{array}$ & $\begin{array}{l}-0.0402 * * \\
(0.018)\end{array}$ & & & $\begin{array}{l}-0.0284 \\
(0.017)\end{array}$ & $\begin{array}{l}-0.0409 * * \\
(0.018)\end{array}$ \\
\hline Gini coefficient & & & $\begin{array}{l}-0.0062 \\
(0.009)\end{array}$ & $\begin{array}{l}-0.0147 \\
(0.012)\end{array}$ & & & $\begin{array}{l}-0.0048 \\
(0.009)\end{array}$ & $\begin{array}{l}-0.0116 \\
(0.012)\end{array}$ \\
\hline unemployed & & & & $\begin{array}{l}-0.0862^{*} \\
(0.051)\end{array}$ & & & & $\begin{array}{l}-0.0880^{*} \\
(0.051)\end{array}$ \\
\hline male & & & & $\begin{array}{l}0.0930 * * * \\
(0.024)\end{array}$ & & & & $\begin{array}{l}0.0927^{* * *} \\
(0.024)\end{array}$ \\
\hline education level & & & & $\begin{array}{l}-0.0630 * * * \\
(0.016)\end{array}$ & & & & $\begin{array}{l}-0.0631^{* * *} \\
(0.016)\end{array}$ \\
\hline age & & & & $\begin{array}{l}0.0089 * * * \\
(0.002)\end{array}$ & & & & $\begin{array}{l}0.0090^{* * *} \\
(0.002)\end{array}$ \\
\hline constant & $\begin{array}{l}4.6768^{* * *} \\
(0.363)\end{array}$ & $\begin{array}{l}4.8989 * * * \\
(0.374)\end{array}$ & $\begin{array}{l}5.9321 * * * \\
(0.829)\end{array}$ & $\begin{array}{l}6.9649 * * * \\
(0.925)\end{array}$ & $\begin{array}{l}2.1457 \\
(1.646)\end{array}$ & $\begin{array}{l}3.1835^{*} \\
(1.723)\end{array}$ & $\begin{array}{l}4.0677^{*} \\
(2.250)\end{array}$ & $\begin{array}{l}5.9413^{* * *} \\
(1.889)\end{array}$ \\
\hline $\begin{array}{l}\text { Country \& year FE's } \\
N\end{array}$ & $\begin{array}{l}\text { Yes } \\
62153\end{array}$ & $\begin{array}{l}\text { Yes } \\
62153\end{array}$ & $\begin{array}{l}\text { Yes } \\
60166\end{array}$ & $\begin{array}{l}\text { Yes } \\
57807\end{array}$ & $\begin{array}{l}\text { Yes } \\
62153\end{array}$ & $\begin{array}{l}\text { Yes } \\
62153\end{array}$ & $\begin{array}{l}\text { Yes } \\
60166\end{array}$ & $\begin{array}{l}\text { Yes } \\
57807\end{array}$ \\
\hline Countries & 22 & 22 & 22 & 22 & 22 & 22 & 22 & \\
\hline $\mathrm{R}^{2}$ & 0.0349 & 0.0356 & 0.0349 & 0.0450 & 0.0350 & 0.0356 & 0.0349 & 0.0450 \\
\hline
\end{tabular}

where the $\eta_{t}$ 's denote a full set of time effects that capture common shocks to individuals' political preferences, the $\eta_{j}$ 's denote a full set of country dummies that capture any timeinvariant characteristics of country $j$ that affect individual $i$ 's political preference, and $u_{i, j, t}$ is an error term that captures all other factors, with $E\left(u_{i, j, t}\right)=0$ for all individuals $i$, in country $y$ and all time periods $t$. In all of the results we report standard errors that have been clustered at the country/year level.

Results. The results are reported in Table 5. In columns $1-4$, we consider the effect of variety in levels, while columns $5-8$ consider the effect of variety in logs. In columns 1 and 5 , we report the unconditional effect of variety on left-right positioning and note that the effect 
is positive and statistically significant. In other words, in country-years with greater variety of goods, respondents report their political preferences to be further to the right along the left-right spectrum. The other columns of the table look into the interactive effect. With reference to the regression equation specified above, the effect of increased goods variety among the poor respondents is given by $\beta_{1}$, whereas the effect of increased goods variety among the not poor respondents is given by $\beta_{1}+\beta_{3}$. From the regressions that use variety in levels (in columns $2-4$ ), it is clear that the average, unconditional effect is being driven by the not poor respondents. The effect is not statistically significant among poor respondents, but it positive and statistically significant among the not poor respondents. This heterogeneous result is robust to using the log of goods variety (in columns $6-8$ ). The result confirms an important assumption of our theoretical model, namely that the marginal value of disposable revenue increases with the variety of goods, but the gains are concentrated among relatively rich individuals who consume disproportionately the diversified good. A series of online appendix tables shows that the results are robust to estimation with ordered probit and to estimation using our alternative measure of goods diversity that focuses on the variety of consumable goods.

\section{Concluding Remarks}

This paper has presented a novel explanation for the observed decline in income tax rates in the advanced democracies over the last decades, which the standard workhorse political economic theories of fiscal redistribution are not able to explain. In a probabilistic voting framework we have shown that the rise in the diversity of goods over the same period may have increased the marginal utility of income for high-income individuals, who disproportionately consume a diverse array or consumer goods, and may have strengthened political preferences against fiscal redistribution.

To our knowledge, this is the first paper to examine redistribution issues when preferences 
are non-homothetic, an environment in which an increase in goods diversity modifies the relative price index faced by low-income and high-income consumers. Our framework could be applied to the more general case in which the relative price index of consumption for the poor and the rich shifts (for whatever reason). With non-homothetic preferences, changes in the relative price indexes modify the marginal utility of one extra currency unit differently across classes and modifies political preferences and the voting equilibrium as a result.

We have also provided some empirical support for our theoretical results. Using data on the variety of traded goods we have shown that an increase in the diversity of consumer goods is related to a decrease in taxation and in government expenditure. We moreover have shown that such an increase shifts political preferences to the right, and all the more so for richer voters, in line with our theoretical reasoning.

These findings call for further research, notably in understanding the effect of trade on consumption. It would be worthwhile disentangling the diversity effect (highlighted in this paper) from the price effect analyzed in the trade literature (Fajgelbaum and Khandelwal, 2016). From a theoretical point of view, it might also by useful to challenge our findings in the case of vertical differentiation. Although the main mechanisms should remain, notably if the increase in variety comes from high quality goods consumed by high-income earners (Feenstra and Romalis, 2014), their implications in terms of preferences might change.

\section{References}

Acemoglu, D., S. Naidu, P. Restrepo, and J. A. Robinson (2015). Democracy, redistribution, and inequality. In A. B. Atkinson and F. Bourguignon (Eds.), Handbook of Income Distribution, pp. 1885 - 1966. Elsevier.

Arkolakis, K., S. Demidova, P. Klenow, and A. Rodriguez-Clare (2008). The gains from trade with endogenous variety. American Economic Review: Papers and Proceedings 98(4), 444450 .

Austin-Smith, D. (1987). Interest groups, campaign contributions, and probabilistic voting. Public Choice 54, 123-139. 
Autor, D. H. and D. Dorn (2013). The growth of low-skill service jobs and the polarization of the U.S. labor market. American Economic Review 103(5), 1553-1597.

Becker, G. S. (1983). A theory of competition among pressure groups for political influence. Quarterly Journal of Economics 98(3), 371-400.

Bénabou, R. (1996). Inequality and growth. In NBER Macroeconomics Annual 1996, Volume 11, pp. 11-92. MIT Press.

Bénabou, R. and E. A. Ok (2001). Social mobility and the demand for redistribution: The POUM hypothesis. Quarterly Journal of Economics 116(2), 447-487.

Bierbrauer, F. and P. Boyer (2013). Political competition and Mirrleesian income taxation: A first pass. Journal of Public Economics 103, 1-14.

Bils, M. and P. J. Klenow (2001). The acceleration in variety growth. American Economic Review 91, 274-280.

Bonica, A., N. McCarty, K. T. Poole, and H. Rosenthal (2013). Why hasn't democracy slowed rising inequality? The Journal of Economic Perspectives 27(3), 103-123.

Borck, R. (2007). Voting, inequality and redistribution. Journal of Economic Surveys 21(1), 90-109.

Bourlès, R., M. T. Dorsch, and P. Maarek (2014). Income redistribution and the diversity of consumer goods. THEMA Working Papers 2014-21.

Broda, C. and D. E. Weinstein (2004). Variety growth and world welfare. American Economic Review: Papers and Proceedings 94(2), 139-144.

Broda, C. and D. E. Weinstein (2006). Globalization and the gains from variety. Quarterly Journal of Economics 121(2), 541-585.

Chetty, R. (2006). A new method of estimating risk aversion. American Economic Review $96(5), 1821-1834$.

Chirinko, R. S. and D. J. Wilson (2017). Tax competition among US states: Racing to the bottom or riding on a seesaw? Journal of Public Economics 155, 147-163.

Choi, G., I. Kim, and A. Snow (2001). Comparative statics predictions for changes in uncertainty in the portfolio and savings problems. Bulletin of Economic Research 53(1), $61-72$.

Coe, D. T., E. Helpman, and A. W. Hoffmaister (2009). International R\&D spillovers and institutions. European Economic Review 53(7), 723-741.

Corneo, G. and H. P. Gruner (2000). Social limits to redistribution. American Economic Review 90 (5), 1491-1507. 
Dixit, A. and J. Londregan (1996). The determinants of success of special interests in redistributive politics. The Journal of Politics 58(4), 1132-1155.

Dixit, A. K. and J. E. Stiglitz (1977). Monopolistic competition and optimum product diversity. American Economic Review 67(3), 297-308.

Dorsch, M. (2010). Social mobility and the demand for public consumption expenditures. Public Choice 142(1-2), 25-39.

Eeckhoudt, L., J. Etner, and F. Schroyen (2009). The values of relative risk aversion and prudence: A context-free interpretation. Mathematical Social Sciences 58(1), 1-7.

Engel, E. (1857). Die productions-und consumptionsverhaltnisse des konigreichs. Zeitschrift des Statistischen Bureaus des Koniglich Sdchsischen Ministerium des Inneren 8.

Epple, D. and T. Romer (1991). Mobility and redistribution. Journal of Political Economy $99(4), 828-58$.

Fajgelbaum, P., G. M. Grossman, and E. Helpman (2011). Income distribution, product quality, and international trade. Journal of Political Economy 119(4), 721-765.

Fajgelbaum, P. D. and A. K. Khandelwal (2016). Measuring the unequal gains from trade. The Quarterly Journal of Economics 131(3), 1113.

Feenstra, R. C. and J. Romalis (2014). International prices and endogenous quality. The Quarterly Journal of Economics 129(2), 477-527.

Financial Times (2013). US public investment falls to lowest level since war. Nov. 03 2013, by Robin Harding, Richard McGregor, and Gabriel Muller.

Gaulier, G. and S. Zignago (2010). Baci: International trade database at the product-level. CEPII Working Paper, N2010-23.

Gradstein, M. and B. Milanovic (2004). Does liberté= égalité? A survey of the empirical links between democracy and inequality with some evidence on the transition economies. Journal of Economic Surveys 18(4), 515-537.

Grossman, G. M. and E. Helpman (2001). Special Interest Politics. Cambridge, MA: MIT Press.

Gupta, S. and M. Keen (2014). Fiscal policy and income inequality. IMF Policy Paper 2012034.

Hadar, J. and T. K. Seo (1990). The effects of shifts in a return distribution on optimal portfolios. International Economic Review 31(3), 721-36.

Harms, P. and S. Zink (2003). Limits to redistribution in a democracy: A survey. European Journal of Political Economy 19(4), 651-668. 
Harris, E. and F. Sammartino (2011). Trends in the distribution of household income between 1979 and 2007. Congress of the United States, Congressional Budget Office.

Henry, L. (2014). Income inequality and income-class consumption patterns. Economic Commentary (Oct).

Henry, L. (2015). Income growth and the impact of relative price changes on age-based consumption patterns. Economic Commentary (July).

Heritage Foundation (2016). Index of Economic Freedom. http://www.heritage.org/index/.

Hummels, D. and P. J. Klenow (2005). The variety and quality of a nation's exports. American Economic Review 95(3), 704-723.

Isen, A. (2014). Do local government fiscal spillovers exist? Evidence from counties, municipalities, and school districts. Journal of Public Economics 110, 57-73.

Kleven, H. J., C. Landais, and E. Saez (2013). Taxation and international migration of superstars: Evidence from the European football market. American Economic Review 103(5), 1892-1924.

Kleven, H. J., C. Landais, E. Saez, and E. Schultz (2014). Migration and wage effects of taxing top earners: Evidence from the foreigners' tax scheme in Denmark. The Quarterly Journal of Economics 129(1), 333.

Krugman, P. R. (1979). Increasing returns, monopolistic competition, and international trade. Journal of International Economics 9(4), 469-479.

Latzer, H. and F. Mayneris (2012). Income distribution and vertical comparative advantage: Theory and evidence. CORE Discussion Papers 2012034.

Lindbeck, A. and J. Weibull (1987). Balanced-budget redistribution as the outcome of political competition. Public Choice 52(3), 273-297.

Martinez, I. Z. (2016). Beggar-thy-neighbour tax cuts: Mobility after a local income and wealth tax reform in Switzerland. Economics Working Paper Series 1608, University of St. Gallen, School of Economics and Political Science.

Matsuyama, K. (2002). The rise of mass consumption societies. Journal of Political Economy $110(5), 1035-1070$.

Meltzer, A. H. and S. F. Richard (1981). A rational theory of the size of government. Journal of Political Economy 89(5), 914-27.

Parchet, R. (2014). Are Local Tax Rates Strategic Complements or Strategic Substitutes? IdEP Economic Papers 1407, USI Universit della Svizzera italiana.

Piketty, T. (2014). Capital in the Twenty-First Century. Cambridge, MA: Harvard University Press. 
Roberts, K. W. (1977). Voting over income tax schedules. Journal of Public Economics 8(3), 329-340.

Roemer, J. E. (1998). Why the poor do not expropriate the rich: An old argument in new garb. Journal of Public Economics 70(3), 399-424.

Romer, T. (1975). Individual welfare, majority voting, and the properties of a linear income tax. Journal of Public Economics 4(2), 163-185.

Slemrod, J. and J. Bakija (2008). Taxing Ourselves: A Citizen's Guide to the Debate over Taxes, Fourth edition. Cambridge, MA: MIT Press.

Solt, F. (2009). Standardising the World Income Inequality Database. Social Science Quarterly 90(2), 231-242. SWIID Version 4.0, September 2013.

Wilson, J. D. (1999). Theories of tax competition. National Tax Journal 52(2), 269-304.

World Bank (2016). World Development Indicators. Washington DC: The World Bank Group.

\section{Appendix}

\section{Proof of Remark 1}

The first-order conditions of the consumer's problem (1) yield the following:

$$
U_{1}(\cdot) p_{i}=U_{2}(\cdot)\left(\sum_{j=1}^{n} q_{j}^{\rho}\right)^{\frac{1}{\rho}-1} q_{i}^{\rho-1}
$$

That is using producers optimal behavior $\left(p_{i}=c / \rho\right)$ and symmetry $\left(q_{i}=q \forall i\right)$ :

$$
\begin{aligned}
& q_{0}^{*}=I-\frac{n c q^{*}}{\rho} \\
& c U_{1}\left(I-\frac{n c q^{*}}{\rho}, n^{\frac{1}{\rho}} q^{*}\right)=n^{\frac{1}{\rho}-1} \rho U_{2}\left(I-\frac{n c q^{*}}{\rho}, n^{\frac{1}{\rho}} q^{*}\right)
\end{aligned}
$$

It then turns out that ${ }^{29}$ :

$$
\frac{\partial q^{*}}{\partial I}=\frac{c U_{11}}{\frac{n c^{2}}{\rho} U_{11}+n^{\frac{2}{\rho}-1} \rho U_{22}} \geq 0 \quad \text { and } \quad \frac{\partial q_{0}^{*}}{\partial I}=1-\frac{n c}{\rho} \frac{\partial q^{*}}{\partial I}=\frac{n^{\frac{2}{\rho}-1} \rho U_{22}}{\frac{n c^{2}}{\rho} U_{11}+n^{\frac{2}{\rho}-1} \rho U_{22}} \geq 0 .
$$

and

\footnotetext{
${ }^{29}$ From now on we omit the arguments of the utility function and its derivatives, which will always be evaluated at the optimum $\left(q_{0}^{*}, Q^{*}\right)$.
} 


$$
\frac{\partial^{2} q^{*}}{\partial I^{2}}=\frac{n^{\frac{2}{\rho}-1} c \rho}{\left[\frac{n c^{2}}{\rho} U_{11}+n^{\frac{2}{\rho}-1} \rho U_{22}\right]^{2}}\left[\frac{\partial q_{0}^{*}}{\partial I} U_{111} U_{22}-\frac{\partial Q^{*}}{\partial I} U_{222} U_{11}\right]
$$

which is positive if and only if :

$$
\begin{aligned}
& & \frac{\partial q_{0}^{*}}{\partial I} U_{111} U_{22}-\frac{\partial Q^{*}}{\partial I} U_{222} U_{11}>0 & \\
\Leftrightarrow & U_{111} U_{22}>\frac{n^{1 / \rho} c U_{11}}{n^{2 / \rho-1} \rho U_{22}} U_{222} U_{11} & & (\text { by }(14)) \\
\Leftrightarrow & U_{111} U_{22}>P \frac{U_{222}}{U_{22}} U_{11}^{2} & & \text { (by definition of } P \text { ) } \\
\Leftrightarrow & \quad \frac{U_{111}}{U_{11}^{2}}<P \frac{U_{222}}{U_{22}^{2}} & & \text { (as } \left.U_{22}<0 \text { and } U_{11}^{2}>0\right)
\end{aligned}
$$

\section{Proof of Remark 2}

For given $\tau_{A}, \tau_{B}$ and $\delta$, the swing voters in each group can be defined as

$$
\sigma^{j}=U^{j}\left(\tau_{A}\right)-U^{j}\left(\tau_{B}\right)-\delta
$$

and the share of votes for candidate $A$ can be expressed as

$$
\Pi_{A}=\sum_{j} \alpha^{j} \phi\left(\sigma^{j}+\frac{1}{2 \phi}\right)
$$

The probability of candidate A winning the election therefore can be written as

$$
P_{A} \equiv \mathbb{P}\left(\Pi_{A} \geq \frac{1}{2}\right)=\mathbb{P}\left(\sum_{j} \alpha^{j} \phi\left(\sigma^{j}+\frac{1}{2 \phi}\right)>\frac{1}{2}\right) .
$$

Using the definition of swing voters, we have that

$$
P_{A}=\mathbb{P}\left(\sum_{j} \alpha^{j} \phi\left[U^{j}\left(\tau_{A}\right)-U^{j}\left(\tau_{B}\right)\right]>\delta \sum_{j} \alpha^{j} \phi\right) .
$$

Defining $\Delta \equiv \frac{1}{\phi} \sum_{j} \alpha^{j} \phi\left[U^{j}\left(\tau_{A}\right)-U^{j}\left(\tau_{B}\right)\right]$ we have $P_{A}=\mathbb{P}(\Delta>\delta)=1-\mathbb{P}(\delta>\Delta)$. Now, given the distribution of $\delta, \mathbb{P}(\delta>\Delta)=\xi\left(\frac{1}{2 \xi}-\Delta\right)=\frac{1}{2}-\Delta \xi$. This gives

$$
P_{A}=\frac{1}{2}+\frac{\xi}{\phi}\left[\sum_{j} \alpha^{j} \phi\left[U^{j}\left(\tau_{A}\right)-U^{j}\left(\tau_{B}\right)\right]\right]
$$

Each candidate maximizes her probability of winning the election. As both candidates maximize the same program, only a symmetric equilibrium can exist in which both candidates 
announce the same platform in equilibrium. As a result, the swing voter in each group is $\sigma^{j}=\delta$. First order condition $\partial P_{A} / \partial \tau_{A}=0$ gives

$$
\frac{\xi}{\phi} \sum_{j} \alpha^{j} \phi \frac{\partial U^{j}\left(\tau_{A}\right)}{\partial \tau_{A}}=0
$$

As $\frac{\partial U^{j}}{\partial \tau_{A}}=\frac{\partial U}{\partial I} \cdot \frac{\partial \widehat{I}^{j}}{\partial \tau_{A}}$ and noting that $\tau \equiv \tau_{A}=\tau_{B}$, remark 2 holds, as $\frac{\partial \widehat{I}^{L}}{\partial \tau}=\frac{\alpha^{H}}{\alpha^{L}} I^{H}$ and $\frac{\partial \widehat{I}^{H}}{\partial \tau}=-I^{H}$

\section{Proof of Proposition 1}

Denoting

$$
U^{*} \equiv U\left(I-\frac{n c q^{*}}{\rho}, n^{1 / \rho} q^{*}\right)
$$

with $q^{*}$ satisfying (13), we first have, using the Envelope Theorem, that

$$
\frac{\partial U^{*}}{\partial n}=\frac{q^{*}}{\rho}\left(n^{\frac{1}{\rho}-1} U_{2}-c U_{1}\right)
$$

As, moreover, by (13), $c U_{1}=n^{\frac{1}{\rho}-1} \rho U_{2} \leq n^{\frac{1}{\rho}-1} U_{2}$, we have that

$$
\frac{\partial U^{*}}{\partial n}=\frac{1-\rho}{\rho} n^{\frac{1}{\rho}-1} q^{*} U_{2}>0 .
$$

Differentiating by $I$ we find that

$$
\frac{\partial^{2} U}{\partial n \partial I}=\frac{1-\rho}{\rho} n^{\frac{1}{\rho}-1} \frac{\partial q^{*}}{\partial I}\left(n^{\frac{1}{\rho}} q^{*} U_{22}+U_{2}\right)=\frac{1-\rho}{\rho n} \frac{\partial Q^{*}}{\partial I}\left(Q^{*} U_{22}+U_{2}\right) .
$$

Differentiating (25) again with respect to $I$, we find

$$
\frac{\partial^{3} U}{\partial n \partial I^{2}}=\frac{1-\rho}{\rho n} \frac{\partial^{2} Q^{*}}{\partial I^{2}}\left(Q^{*} U_{22}+U_{2}\right)+\frac{1-\rho}{\rho n}\left(\frac{\partial Q^{*}}{\partial I}\right)^{2}\left(Q^{*} U_{222}+2 U_{22}\right),
$$

which gives us Proposition 1.

\section{Proof of Remark 3}

Using the vote share $P_{A}$ for candidate $A$ from 20 , the first-order condition $\partial P_{A} / \partial \tau_{A}=0$ gives

$$
\frac{\xi}{\phi} \sum_{j} \alpha^{j} \phi^{j} \frac{\partial U^{j}\left(\tau_{A}\right)}{\partial \tau_{A}}=0
$$

which we can rewrite as:

$$
\frac{\xi}{\phi} \sum_{j} \alpha^{j} \phi\left[\frac{\partial U}{\partial I} \cdot \frac{\partial \widehat{I}^{j}}{\partial \tau_{A}}+\frac{\partial U^{j}}{\partial G} \cdot \frac{\partial G}{\partial \tau_{A}}\right]=0
$$

As $\frac{\partial U^{L}}{\partial G}=\frac{\partial U^{H}}{\partial G}$ (due to our separability assumption), $\frac{\partial \widehat{I}^{L}}{\partial \tau_{A}}=0$ (as there is no pure income redistribution and only the high-income voters bear the tax), noting that $\tau \equiv \tau_{A}=\tau_{B}$ and after rearranging, Remark 3 holds. 